\title{
Affecting Factors that Improve Performance Project with Line of Balance and Critical Path Method at Pier Works in Toll Road Project at Jakarta Indonesia
}

\author{
Barnard Sahat Ramces Hutapea and Suardi Natasaputra
}

Department of Master Program of Civil Engineering

Tama Jagakarsa University, Jakarta Indonesia

\begin{abstract}
The construction of toll roads in Indonesia is an effort by the government to improve the national competitiveness index and the national logistics cost performance index, including through the development of road infrastructure, including toll roads. The Toll road is a road that is devoted to two or more axle vehicles (cars, buses, trucks) and aims to shorten the distance and travel time from one place to another. Toll roads are part of the road network system and national roads for which users are required to pay. The implementation of toll road construction in Jakarta as in other cities has a level of difficulty in carrying out the work due to very high traffic activities, utilities that must be relocated or avoided, of course, have a very high risk as well. These consequences are unfavorable for the project because they will hinder and hinder the achievement of project objectives. Some of the risks in toll road construction work include utilities, land acquisition, window time, and traffic management. The risks mentioned above are some of the causes of delays that occur during the implementation of toll road projects. In determining the factors of delay, this research uses the SPSS (Statistical Product and Service Solutions) method. The method used in determining the ranking of the delay factor is the stepwise method. There were 9 affecting factors, namely job duration analysis, waiting time analysis, repetitive job analysis, decision making, utility, critical path determination, work method approach, innovative way of thinking, and job sequence analysis. The application of the toll road construction work process with scheduling innovation based on the integration of the Line of Balance and the Critical Path Method can optimize project performance in terms of time. The research is expected to produce innovative studies as an alternative to the best recommendations in terms of project time performance for service providers and service providers. By knowing the key factors in the completion of toll road works, this research is expected to be a benchmark or pilot for toll road construction projects, as well as in the application of pier work on toll road projects.
\end{abstract}

Key Words: Line of Balance, Critical Path Method, SPSS, Pier Works, Toll Roads.

\section{INTRODUCTION}

Massive toll road construction in Indonesia is an effort by the government that can improve the national competitiveness index and the national logistics cost performance index, including through the development of road infrastructure, including toll roads. The history of toll roads in Indonesia began in 1978 with the operation of the $59 \mathrm{~km}$ Jagorawi toll road (including access roads), which connected Jakarta, Bogor, and Ciawi. Based on BPJT data, the construction of the toll road, which began in 1975, was carried out by the government with funds from the government budget and foreign loans handed over to PT. Jasa Marga (Persero) Tbk. as equity participation. Next PT. Jasa Marga is assigned by the government to build toll roads with land financed by the government. Starting in 1987, the private sector began to participate in toll road investment as toll road operators by signing a concession agreement (PKP) with PT Jasa Marga. As of 2019, $2100 \mathrm{~km}$ of toll roads have been built in Indonesia. Quoted from news coverage site 6, when giving an oration at the 60th Anniversary of Diponegoro University at Diponegoro University Stadium, Semarang City, Central Java Province, President Joko Widodo (Jokowi) stated that the cost of logistics transportation in Indonesia is 2.5 times more expensive compared to two neighboring countries, namely Malaysia and Singapore. That is, in Indonesia to carry goods from one place to another costs 2 times to 2.5 times more expensive. As a result, goods sold in Indonesia are more expensive than in other countries. The demand for infrastructure in Indonesia is so great considering that infrastructure is needed to boost the economy. However, underinvestment in previous years has led to a large infrastructure deficit and stunted Indonesia's growth, and limited the pace of poverty reduction (The World Bank, 2017). Based on IMF data (2017), the comparison of Public Capital Stock between countries illustrates the size of Indonesia's infrastructure deficit based on Investment 
and Capital Stock (IMF) data in January 2017. Infrastructure capital is an important component of public capital in most countries. The public capital stock also includes a non-infrastructure component.

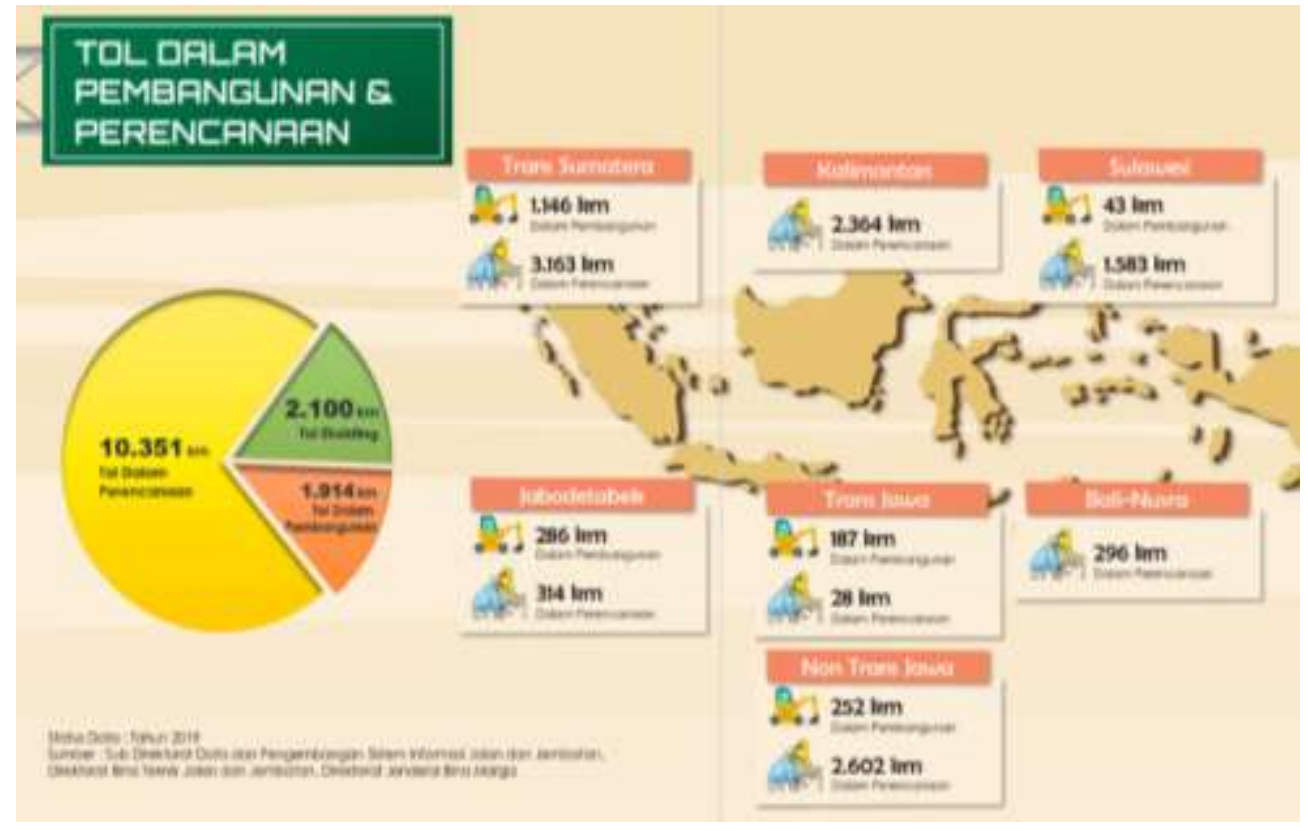

Figure 1.1 Status of toll road data in 2019

According to [1], stating that the integration of the Line of Balance method with the Critical Path Method can provide better planning, the Line of Balance method will provide an analysis of overlapping work on repetitive work items so that the application of the Critical Path Method scheduling method can be applied to analyze the duration of the work and the critical path on the toll road project pier work. Therefore, researchers will analyze pier work based on the integration of the Line of Balance and Critical Path Method on toll road projects, which are expected to provide efficiency and optimization in terms of time to decrease and avoid delays during the implementation of the toll road project development and provide references to contractors, owners who are carrying out construction so that this does not happen. By knowing the key factors in the completion of toll road works, this research is expected to be a benchmark or pilot for toll road construction projects, as well as in the application of pier work on toll road projects. This research is limited to the scheduling stage of project implementation through the perspective of stakeholders as project owners in controlling the duration of work to achieve the goal of optimizing time performance.

\section{LITERATURE REVIEW}

\subsection{Project Risk Management}

A risk is an uncertain event that will come and have a positive or negative impact [2]. Risk can be estimated based on the probability that an event will occur and the impact of that event. To estimate or predict risk, risk management is required. To achieve the objectives in risk management, several stages must be carried out. This stage is useful to make it easier to manage risk. These stages are:

1. Planning Risk Management,

2. Identify Risks,

3. Conducting Qualitative Risk Analysis,

4. Conducting a Quantitative Risk Analysis,

5. Planning Risk Responses, and

6. Controlling Risk.

The first stage is planning risk management, which is the process of determining how to implement risk management in a project. The next step is to identify risks. Risk identification is a stage in determining what risks affect the project and documenting each of its characteristics (Project Management Institute, 2013). This stage is important because in managing risk it is necessary to know what risks can affect a project.

Figure 2.1 describes the risk response categories based on the chance of the risk occurring and the impact caused by the risk. This image is an adaptation of [3]. 


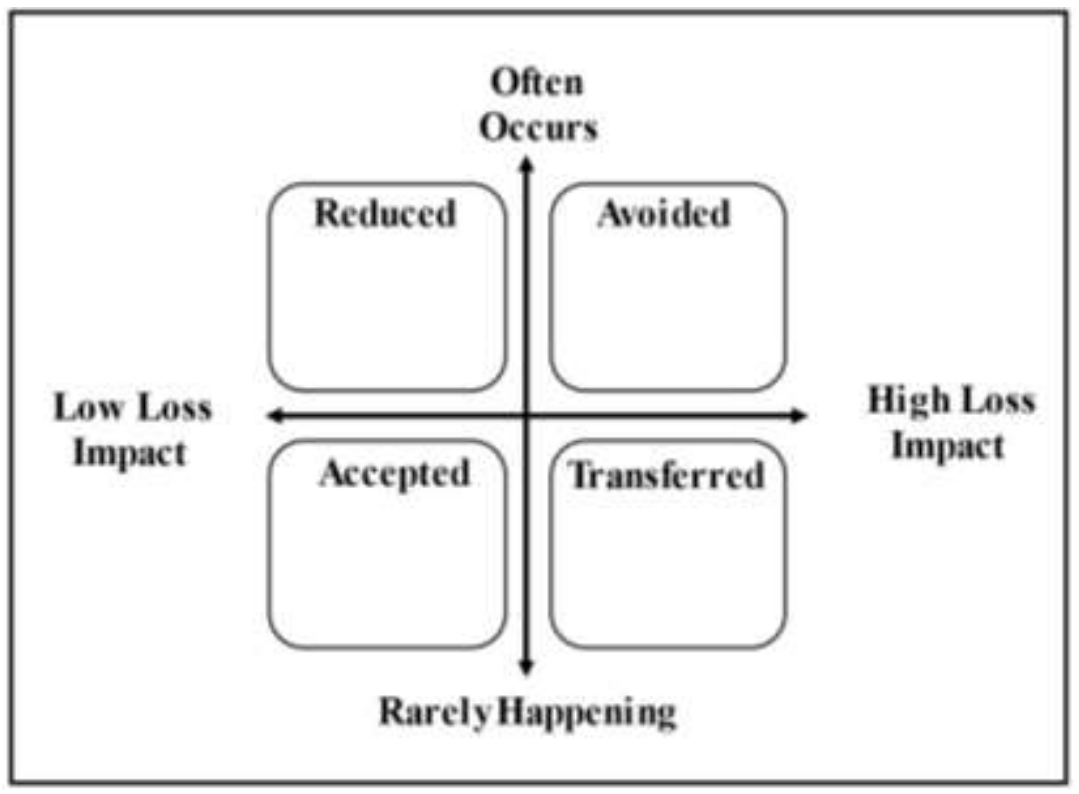

Figure 2.1 Risk response matrix

\subsection{Scheduling}

Scheduling is defined as the process of setting the time of an operation, in general scheduling aims to minimize processing time, waiting time subscriptions, and inventory levels, as well as the efficient use of facilities, manpower, and equipment. Scheduling is prepared with consideration of the limitations that exist [4]. Good scheduling will have a positive impact, namely a low operating cost and delivery time, which can ultimately increase customer satisfaction. Scheduling is a collection of policies and mechanisms in the operating system related to the sequence of work carried out by a computer system [5]. The schedule is the elaboration of project planning into a sequence of steps for implementing work to achieve goals. On schedule has included the time factor

\subsection{Causes of Construction Delays}

According to [6], delays are caused by different parties, namely:

a. The owner or his representative (delay caused by owner). If the owner or his representative causes a delay, for example, due to late submission of working drawings or delay in approving the drawings, the contractor will generally be allowed to obtain a legal claim for extra compensation.

b. Delays caused by contractors (contractor caused delay). This kind of delay will generally result in no extension of time being granted and no additional compensation being awarded. In fact, in extreme situations, these things will cause the contract to be broken.

c. Delays by permitted third parties (excusable third party delays). There are often delays caused by different forces beyond the control of the owner or contractor. Examples that are no longer in question include fires, floods, earthquakes, and other things referred to as "acts of God Almighty". Other things that are often a matter of dispute include strikes, embargoes on the carriage, accidents, and understandable delays in delivery. Including those that are not included in the conditions that existed at the time the offer was made and bad weather conditions. In this case, it can be agreed, the type of delay of these types generally results in an extension of time but not a dissertation with additional compensation.

\subsection{Line of Balance Method (LoB)}

History The Line of Balance method was first implemented by the Good year company in the early 1940s and developed by the US Navy Department for programming and controlling repetitive projects. Later it was further developed by the Nation Building Agency in the UK for recurring housing projects, where the resource-oriented scheduling tool turned out to be more appropriate and realistic than the activity-dominated scheduling method. This method is then adapted for project planning and control [7], where resource productivity is considered as a very important part. The Line of Balance scheduling method is a scheduling method that is usually implemented on jobs that have the same and repetitive characteristics. According to [8], the Line of Balance or linear line scheduling 
method is usually very effective for projects with a relatively small number of activities and is widely used for scheduling with repetitive activities for infrastructure projects such as road construction projects, airport runways, tunnels or industrial manufacturing projects.

The advantage of this method is that it can inform the level of productivity and duration of work in a graphic format that can be read more simply and more easily. In addition, LoB can also inform at a glance what is wrong with the progress of activities and can detect potential disturbances that will come. Thus LoB has a better understanding of projects that have repetitive activities compared to other methods, because LoB has the possibility to regulate the level of activity productivity, has smoothness and efficiency in the flow of resources and requires less time, and effort to produce it than with the network scheduling method.

The Line of Balance is based on the underlying assumption that production levels for activities are uniform. In other words, the production rate of activity is linear where time is plotted on one axis, usually horizontal, and for or activity stages on the vertical axis. The production rate of an activity is the slope of the production line and is expressed in units per time [9]. An example of a line of balance diagram can be seen in Figure 2.2 below:

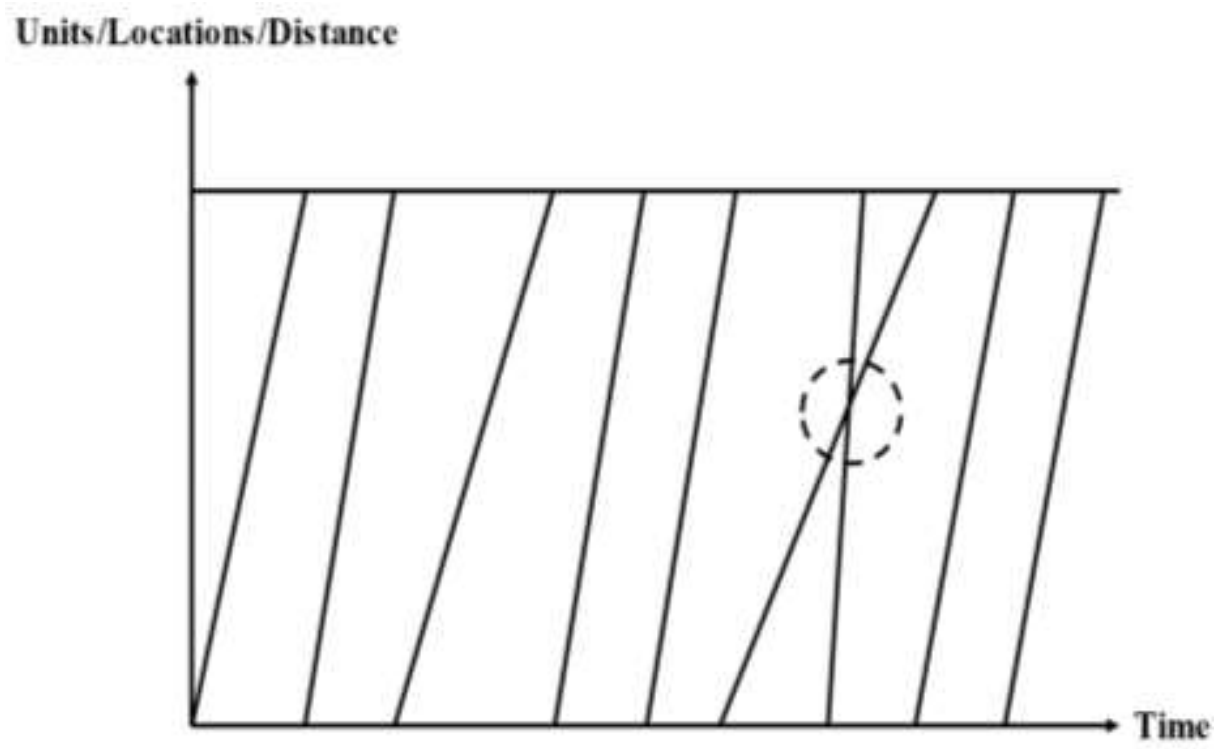

Figure 2.2 Example of a LOB diagram

Description:

1. The vertical axis shows the cumulative progress or percentage of each job that has been completed, while the flat axis shows the time.

2. The diagonal line between the vertical and horizontal axes each represents one activity, the slope of this line shows the average progress of the activity.

3. The intersection between the lines of the diagram representing two activities that must sequentially indicates a conflict between activities, so it must be avoided.

\subsection{Critical Path Method (CPM)}

Critical Path Method or the so-called critical path method is one of the project scheduling methods developed by E.I. du Pont de Nemours \& Company and later expanded by Mauchly Associates. CPM is a traditional scheduling method that still uses spare time for each activity to protect these activities, CPM is one of the scheduling methods that uses a deterministic time estimate. CPM also serves to analyze the network of activities/activities when running a project to predict the total duration. The critical path or critical path is the longest path in a network diagram schedule and has the fewest errors, the critical path of a project is a series of activities that determine the fastest time that can be run so that the project can be completed, by knowing the critical path the project can analyze the manpower needs and resources so that activities that are on the critical path do not experience delays because delays in the critical path can cause delays in the completion of a project. Some things to note regarding the critical path include:

- Delay in work on the critical path will cause delays in the completion of the overall project path

- Completion of the overall project can be accelerated by accelerating the completion of the work on this critical path.

- Slack of critical path jobs is equal to 0 (Zero) this allows relocation of resources from jobs that are not on the critical path into jobs on the critical path. 
CPM (Critical Path Method) or the Critical Path Method is a project activity model described in the form of a network. Activities are depicted as points on the network and events that signify the start or end of activities are depicted as arcs or lines between points. CPM (critical path method) or the Critical Path Method is a series of work items in a project that is a critical part of the overall project completion. This means the timely completion of a job that is included in critical work will cause the project to experience delays because the project completion time will be delayed.

\subsection{Integration of Line of Balance Method with CPM (Critical Path Method)}

Project work that has a repetitive nature for its activities requires scheduling that ensures the use of the activities of an activity does not interfere with other activities both in terms of resources and others and still maintains the limits of dependence on these resources. The CPM (Critical Path Method) method, which is often used for scheduling planning on projects, has a shortage of recurring project scheduling because there will be overlap from one work unit to the next, for that the Line of Balance method is applied at the beginning to analyze activities. which has the potential to overlap and determine the Buffer time so that no resources are waiting for work for other work and then apply the CPM (Critical Path Method) method to determine the amount of work duration and determine the time of floats and project resources for each activity. So it is hoped that the integration of these two methods can provide a more optimal scheduling plan.

\subsection{Infrastructure}

According to [10], infrastructure is a physical system that provides transportation, irrigation, drainage, buildings, and other public facilities, which are needed to meet basic human needs, both social and economic needs. In this case, things related to infrastructure cannot be separated from each other. Environmental systems can be connected because of the infrastructure that supports the social system and the economic system. Infrastructure is a place to support activities in one space.

\subsubsection{Toll Road}

Toll roads are part of the alternative public road network system where users are required to pay tolls. However, in certain circumstances toll roads are not an alternative route (UU 38/2004 Article 44). Government Regulation Number 15 of 2005 states that toll roads are public roads that are part of the road network system and as national roads whose use is required to pay tolls. The construction of toll roads is carried out to facilitate traffic in areas that have developed, increase the usability and efficiency of goods and services distribution services to support increased economic growth, ease the burden of government funds through the participation of road users and increase the distribution of development results and justice (Law 38/ 2004 Article 43 paragraph 1).

\subsubsection{Pier Structure}

Pier structure in toll road construction has its own characteristics because the pier casting consists of several segments depending on the height of the pier itself, while the pier height usually depends on the road or bridge. The toll road consists of a simple beam system resting on bridge piers or reinforced concrete piers and is built along the toll road. Especially for the implementation of piers in traffic-prone lanes, it is predicted that the casting of concrete cantilevers will increase the level of congestion and it can cause project delays.

\section{RESEARCH METHODOLOGY}

This research process contains the flow of research from the beginning to the discovery of hypotheses to answer the problem formulation by conducting scientific research, wherein the process some stages / sequences are adapted to the research framework that has been arranged in the form of a flow chart. The flow chart is prepared based on the formulation and research objectives to be achieved by referring to the project feasibility study [11]. 


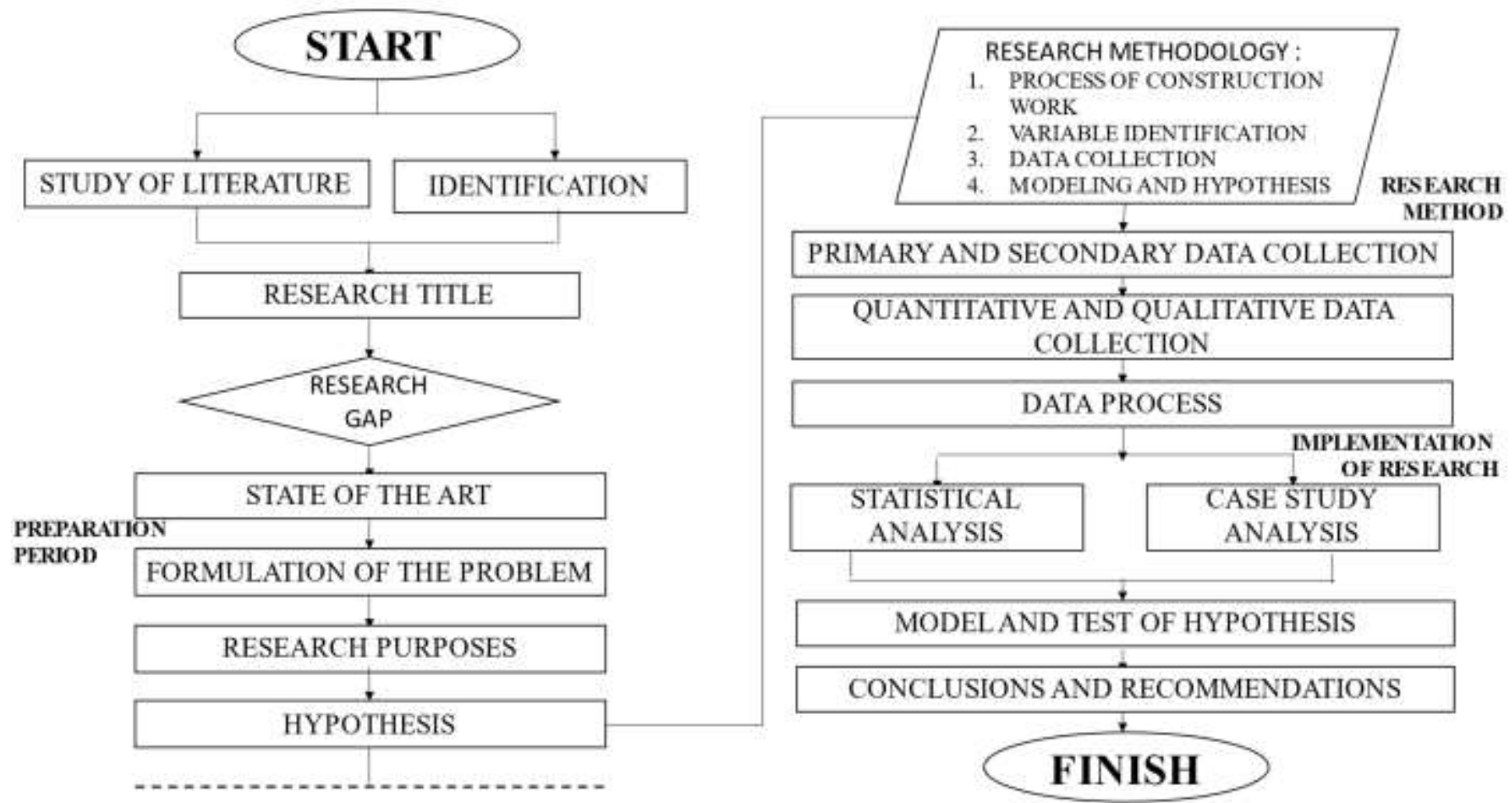

Figure 3.1 Research Flow

The data that has been collected is continued by processing and analyzing the data to get the initial data results. From the findings of the initial data, analysis of the discussion is then carried out to be able to conclude the process of cost, quality, and time efficiency.

\subsection{Identification Variables}

In this case, the researcher took 1 (one) main variable to get time accuracy as the independent variable, and 3 (three) variables as the dependent variable. The variables are:

Dependent Variable: $\quad \mathrm{X} 1=$ Productivity and Pier Design

X2 = Scheduling Line of Balance and Critical Path Method

X3 = Management, Resources, and External Factors of the toll road

Independent Variable: $\quad \mathrm{Y}=$ Time

Respondents used in this study amounted to 60 respondents. The following factors affect to increase in time performance:

Table 3.1 Key success factors

\begin{tabular}{|c|c|c|c|c|c|}
\hline No & Variable & Main Factor & & Sub Factor & Reference \\
\hline 1 & \multirow{11}{*}{$\mathrm{X} 1$} & \multirow{11}{*}{$\begin{array}{l}\text { Productivity and } \\
\text { Design Pier }\end{array}$} & $\mathrm{X} 1 \_1$ & Design error & $\begin{array}{l}\text { Love et al, (2002), Prianto et al } \\
\text { (2012), Riemer et al, (2016) }\end{array}$ \\
\hline 2 & & & $\mathrm{X} 1 \_2$ & Lack of preparation work & Brodetskaia et al (2011) \\
\hline 3 & & & $\mathrm{X} 1 \_3$ & How innovative thinking & Verduyn, 2002 \\
\hline 4 & & & $\mathrm{X} 1 \_4$ & Unclear details & $\begin{array}{l}\text { Love et al (2002), Prianto (2012), } \\
\text { Assaf et al (2006) }\end{array}$ \\
\hline 5 & & & $\mathrm{X} 1 \_5$ & Working method approach & Zakaria et al 2017 \\
\hline 6 & & & X1_6 & Work location & Kent et al, 2018 \\
\hline 7 & & & $\mathrm{X} 1 \_7$ & Lack of control & $\begin{array}{l}\text { Love \& Swinney, 1996, prianto,2012, } \\
\text { Brodetskaia, Sacks, \& Shapira, } 2011\end{array}$ \\
\hline 8 & & & X1_8 & Delay shopdrawing & Sugiharto Alwi, 2002 \\
\hline 9 & & & X1_9 & Design changes & Sugiharto Alwi,2002, Van et al,2010 \\
\hline 10 & & & $\mathrm{X} 1 \_10$ & Specifications Unclear & Sugiharto Alwi,2002 \\
\hline 11 & & & $\mathrm{X} 1 \_11$ & Integrity performance & Cooke et al,2002 \\
\hline
\end{tabular}


International Journal of Engineering Research and Advanced Technology, Vol. 7, No.9, September -2021

\begin{tabular}{|c|c|c|c|c|c|}
\hline 12 & & & $\mathrm{X} 1 \_12$ & Human resource capacity & Pinto et al,1987 \\
\hline No & Variable & Main Factor & & Sub Factor & Reference \\
\hline 13 & \multirow{9}{*}{$\mathrm{X} 2$} & \multirow{9}{*}{$\begin{array}{l}\text { LOB and CPM } \\
\text { scheduling }\end{array}$} & $\mathrm{X} 2 \_1$ & Job duration analysis & Arditi et al, 1986 \\
\hline 14 & & & $\mathrm{X} 2 \_2$ & Labor analysis & Mohammad A.Amar et al, 2013 \\
\hline 15 & & & $\mathrm{X} 2 \_3$ & Buffer time analysis & Mohammad A.Amar et al, 2013 \\
\hline 16 & & & $\mathrm{X} 2 \_4$ & Repetitive job analysis & Arditi et al, 1986 \\
\hline 17 & & & $\mathrm{X} 2 \_5$ & Resource analysis & Mohammad A.Amar et al, 2013 \\
\hline 18 & & & $\mathrm{X} 2 \_6$ & Relationship between activities & Sanjaya dan Syahrizal, 2015 \\
\hline 19 & & & $\mathrm{X} 2 \_7$ & Critical path determination & Yamin et al, 2001 \\
\hline 20 & & & $\mathrm{X} 2 \_8$ & Job sequence analysis & $\begin{array}{l}\text { Syahrizal et al, 2015, Hinze et al, } \\
2010\end{array}$ \\
\hline 21 & & & X2_9 & Project time optimization & Shrestha et al,2016 \\
\hline 22 & \multirow{13}{*}{$\mathrm{X} 3$} & \multirow{13}{*}{$\begin{array}{l}\text { Management, } \\
\text { Resources and } \\
\text { External Factors }\end{array}$} & X3_1 & Vendor selection strategy & Chang et al, 2016 \\
\hline 23 & & & $\mathrm{X} 3 \_2$ & Socio-political conditions & Morris et al, 1987 \\
\hline 24 & & & X3_3 & Weather conditions & Zakaria et al, 2017 \\
\hline 25 & & & X3_4 & Decision-making & Derrick et al, 2011 \\
\hline 26 & & & X3_5 & Project team experience & Derrick et al, 2011 \\
\hline 27 & & & X3_6 & Lack of teamwork & $\begin{array}{l}\text { Love et al, 1996, Proanto et al, 2012, } \\
\text { Brodetskaia et al., } 2011\end{array}$ \\
\hline 28 & & & $\mathrm{X} 3 \_7$ & $\begin{array}{l}\text { Coordination and integration } \\
\text { within the team }\end{array}$ & Chang et al 2016 \\
\hline 29 & & & $\mathrm{X} 3 \_8$ & Utilities & Chang et al 2016 \\
\hline 30 & & & X3_9 & Land acquisition & Derrick et al 2011 \\
\hline 31 & & & X3_10 & Support from top management & Pinto et al 1987 \\
\hline 32 & & & X3_11 & Honesty to reward performance & Chang et al, 2016 \\
\hline 33 & & & X3_12 & $\begin{array}{l}\text { Good communication with } \\
\text { stakeholders }\end{array}$ & Yang et al 2009 \\
\hline 34 & & & X3_13 & Payment accuracy & Chang et al 2016 \\
\hline 35 & \multirow{5}{*}{ Y1 } & \multirow{5}{*}{ Time } & Y1_1 & Determination of time duration & Chang et al, 2002 \\
\hline 36 & & & Y1_2 & Project time optimization & Talekar et al, 2014 \\
\hline 37 & & & Y1_3 & Late work before & Syahrizal et al, 2015 \\
\hline 38 & & & Y1_4 & Project uncertainty risk & Egbu et al, 1998 \\
\hline 39 & & & Y1_5 & Work complexity & Chang et al, 2002 \\
\hline
\end{tabular}

\subsection{Determination of Number of Respondents}

The minimum number of respondents to answer the questionnaire is required as a limitation in collecting the required results. According to [12] the needs of respondents can be obtained by using the following equation:

$\mathrm{m}=\frac{\mathrm{Z}^{2} \times \mathrm{P} \times(1-\mathrm{P})}{\varepsilon^{2}}$

$\mathrm{n}=\frac{\mathrm{m}^{\varepsilon^{2}}}{1+\frac{(\mathrm{m}-1)}{\mathrm{N}}}$

Where: $\mathrm{N}=68, \varepsilon=0,05, \mathrm{P}=0,5$

$\mathrm{p}-$ value $=\frac{1-\varepsilon}{2}=\frac{1-0,05}{2}=0,475$

Based on the $\mathrm{p}$-value, the $\mathrm{Z}$ value is obtained based on the $\mathrm{Z}$ table of normal distribution, $\mathrm{Z}=1.96$. Then the respondents the following minimum requirements:

$\mathrm{m}=\frac{\mathrm{Z}^{2} \times \mathrm{P} \times(1-\mathrm{P})}{\varepsilon^{2}}=\mathrm{m}=\frac{1,96^{2} \times 0,5 \times 0,5}{0,05^{2}}=\frac{0,96}{0,0025}=384,16$

$\mathrm{n}=\frac{\mathrm{m}}{1+\frac{(\mathrm{m}-1)}{\mathrm{N}}}=\mathrm{n}=\frac{384,16}{1+\frac{(384,16-1)}{68}}=57,77$

Therefore, the minimum requirement of respondents is 58 respondents 


\subsection{Data Processing Stage}

The validity test itself, a measure that can show the validity or validity of the instrument. So in testing the validity it refers to an instrument in carrying out its functions. The variables are obtained from journals, articles, and e-books that can be published. The process of testing the validity and reliability is carried out using the following tools in the SPSS program, the following is a data processing flowchart:

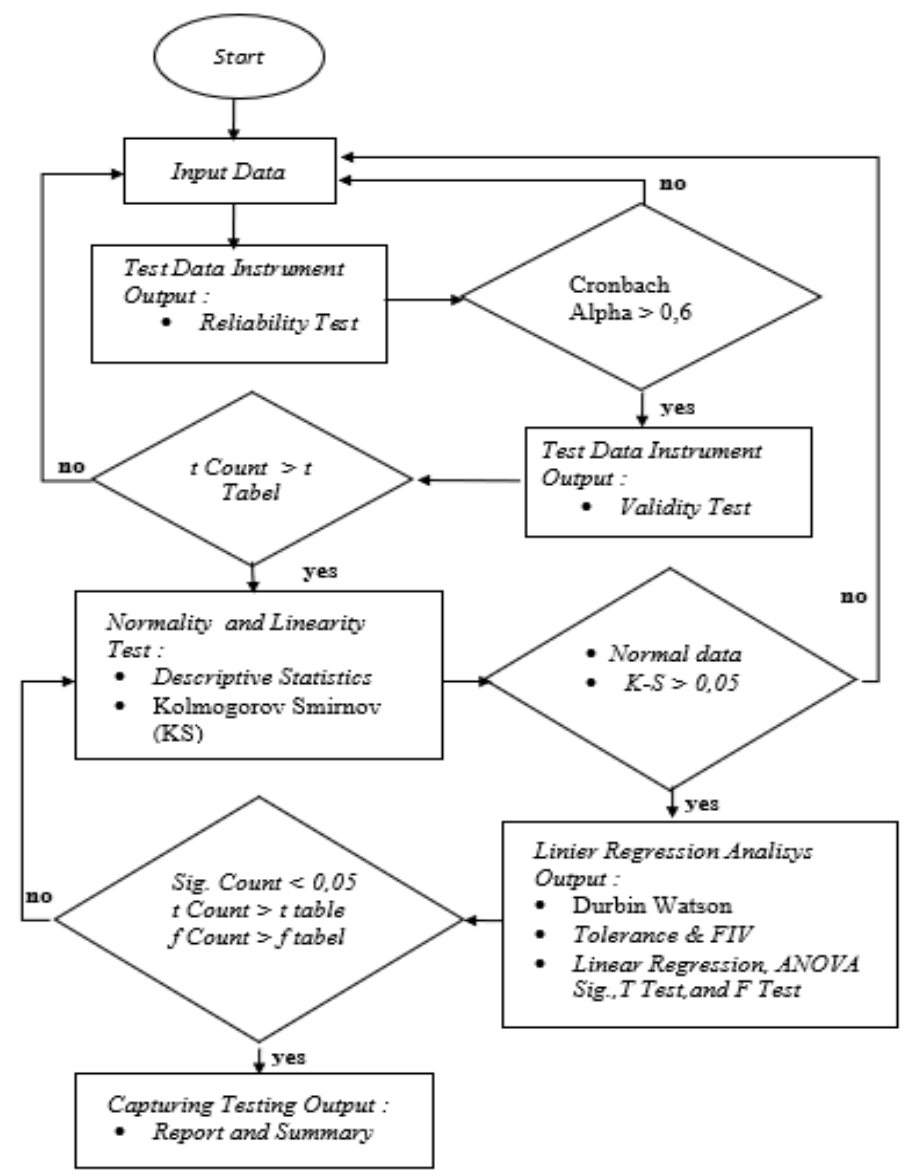

Figure 3.2 Flowchart SPSS

\subsubsection{Validity Test and Reliability Test}

Each variable will be tested using SPSS tools, namely the corrected item-total correlation (calculated validity) if the value is more than 0.2542 then it can be declared valid and the Cronbach's Alpha value (Calculated Reliability). If the value is more than 0.600 then can be declared reliable, following the results of the data grouping are reliable and valid.

Table 3.2 Validity Test Results

\begin{tabular}{|l|c|c|c|}
\hline \multicolumn{1}{|c|}{ Variable } & $\begin{array}{c}\text { Alpha } \\
\text { Cronbach }\end{array}$ & $\begin{array}{c}\text { Comparison } \\
\text { Value }\end{array}$ & Description \\
\hline Productivity and Design Pier & 0,581 & 0.2542 & Valid \\
\hline $\begin{array}{l}\text { Scheduling Line of Balance and } \\
\text { Critical Path Method }\end{array}$ & 0.614 & 0.2542 & Valid \\
\hline $\begin{array}{l}\text { Resource Management and } \\
\text { External Factors }\end{array}$ & 0.604 & 0.2542 & Valid \\
\hline Time & 0.663 & 0.2542 & Valid \\
\hline
\end{tabular}

Table 3.3 Reliability Test Results

Variable

Alpha

Cronbach

Comparison

Description 
International Journal of Engineering Research and Advanced Technology, Vol. 7, No.9, September -2021

\begin{tabular}{|l|c|c|c|}
\hline Productivity and Design Pier & 0,824 & $>0,600$ & Reliable \\
\hline $\begin{array}{l}\text { Scheduling Line of Balance and } \\
\text { Critical Path Method }\end{array}$ & 0,787 & $>0,600$ & Reliable \\
\hline $\begin{array}{l}\text { Resource Management and } \\
\text { External Factors }\end{array}$ & 0,833 & $>0,600$ & Reliable \\
\hline Time & 0,659 & $>0,600$ & Reliable \\
\hline
\end{tabular}

The results of the stepwise regression analysis are then compiled into a recapitulation which is presented in the form of sub-factor rankings. The results of the recapitulation of statistical analysis using the average method for more details can be seen in the discussion below.

Table 3.4 Results of Stepwise Regression Analysis

\begin{tabular}{|c|c|c|c|c|c|c|c|c|c|c|}
\hline \multirow[b]{2}{*}{ Model } & \multirow[b]{2}{*}{$\begin{array}{c}\text { Variables } \\
\text { Entered }\end{array}$} & \multirow[b]{2}{*}{$\mathrm{R}$} & \multirow[b]{2}{*}{$\begin{array}{c}\mathrm{R} \\
\text { Square }\end{array}$} & \multirow[b]{2}{*}{$\begin{array}{l}\text { Adjusted } \\
\text { R Square }\end{array}$} & \multirow[b]{2}{*}{$\begin{array}{l}\text { Std. Error of } \\
\text { the Estimate }\end{array}$} & \multicolumn{5}{|c|}{ Change Statistics } \\
\hline & & & & & & $\begin{array}{c}\text { R Square } \\
\text { Change }\end{array}$ & $\begin{array}{c}\mathrm{F} \\
\text { Change }\end{array}$ & df1 & df2 & $\begin{array}{c}\text { Sig. F } \\
\text { Change }\end{array}$ \\
\hline 1 & $\mathrm{X} 2 \_1$ & $0,544^{\mathrm{a}}$ & 0,296 & 0,284 & 0,3878 & 0,296 & 24,379 & 1 & 58 & 0,000 \\
\hline 2 & $\mathrm{X} 2 \_3$ & $0,643^{\mathrm{b}}$ & 0,413 & 0,392 & 0,3572 & 0,117 & 11,345 & 1 & 57 & 0,001 \\
\hline 3 & $\mathrm{X} 2 \_4$ & $0,716^{\mathrm{C}}$ & 0,513 & 0,487 & 0,3283 & 0,100 & 11,490 & 1 & 56 & 0,001 \\
\hline 4 & X3_4 & $0,778^{\mathrm{d}}$ & 0,605 & 0,576 & 0,2984 & 0,092 & 12,782 & 1 & 55 & 0,001 \\
\hline 5 & X3_8 & $0,802^{\mathrm{e}}$ & 0,643 & 0,609 & 0,2864 & 0,038 & 5,719 & 1 & 54 & 0,020 \\
\hline 6 & $\mathrm{X} 2 \_7$ & $0,829^{\mathrm{f}}$ & 0,688 & 0,653 & 0,2700 & 0,046 & 7,741 & 1 & 53 & 0,007 \\
\hline 7 & X1_5 & $0,846^{\mathrm{g}}$ & 0,716 & 0,678 & 0,2601 & 0,028 & 5,090 & 1 & 52 & 0,028 \\
\hline 8 & X1_3 & $0,864^{\mathrm{h}}$ & 0,746 & 0,706 & 0,2484 & 0,030 & 6,013 & 1 & 51 & 0,018 \\
\hline 9 & X2_8 & $0,876^{1}$ & 0,767 & 0,725 & 0,2404 & 0,021 & 4,479 & 1 & 50 & 0,039 \\
\hline
\end{tabular}

Table 3.5 Results of Stepwise Regression Analysis

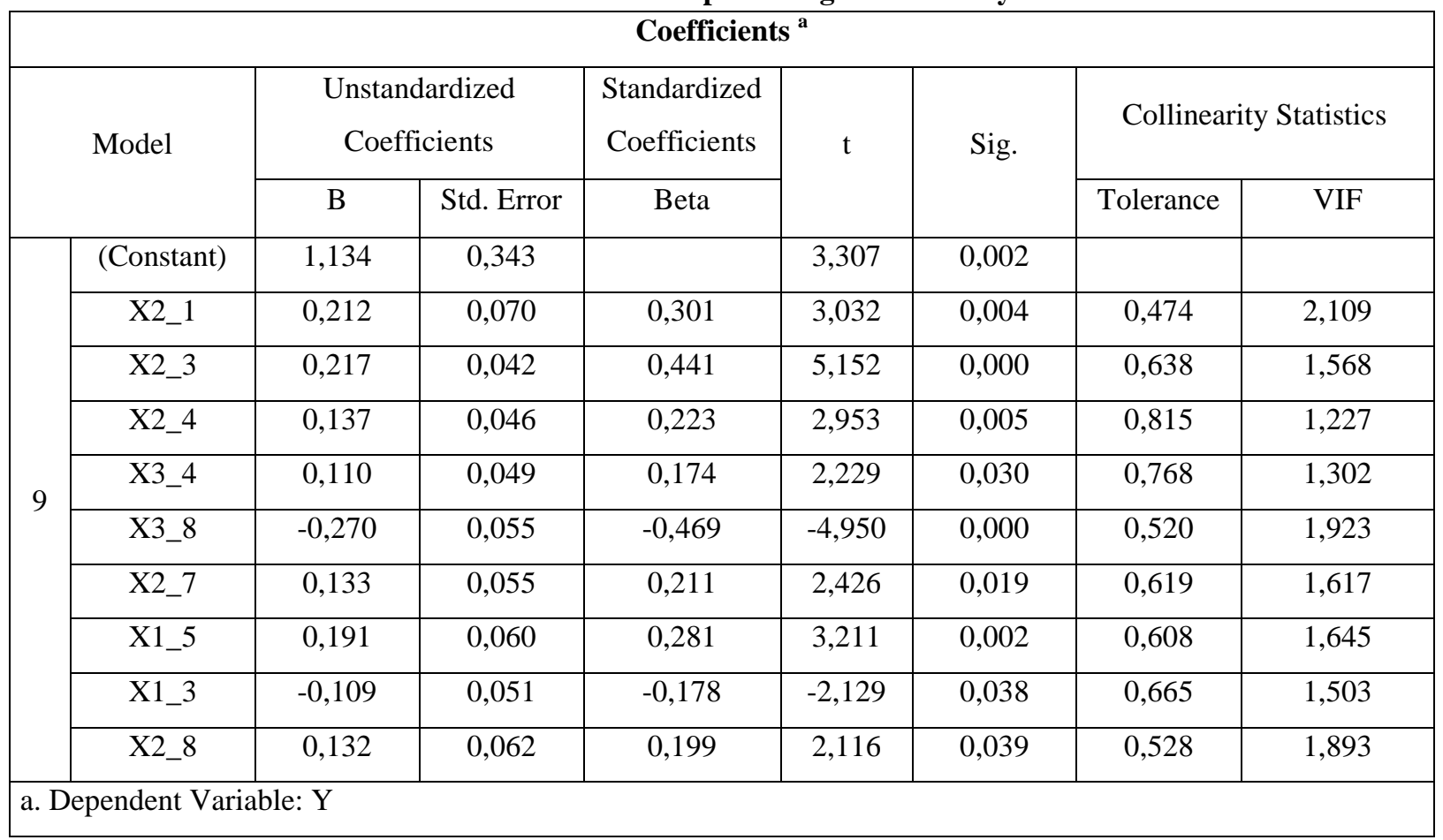




\section{CONCLUSION}

From the above results and experience in the field, it was found that the 9 most affecting factors in the delay in pier work on toll road projects are as shown in table 4.1 .

Table 4.1 the most affecting factors

\begin{tabular}{|c|l|l|}
\hline No & Variable & \multicolumn{1}{|c|}{ Factor } \\
\hline 1 & X2_1 & Job duration analysis \\
\hline 2 & X2_3 & Buffer time analysis \\
\hline 3 & X2_4 & Repetitive job analysis \\
\hline 4 & X3_4 & Decision-making \\
\hline 5 & X3_8 & Utilities \\
\hline 6 & X2_7 & Critical path determination \\
\hline 7 & X1_5 & Working method approach \\
\hline 8 & X1_3 & How innovative thinking \\
\hline 9 & X2_8 & Job sequence analysis \\
\hline
\end{tabular}

\section{REFERENCE}

[1] M. A. Ammar, "LOB and CPM Integrated Method for Scheduling Repetitive Projects," J. Constr. Eng. Manag., 2012, doi: 10.1061/(asce)co.1943-7862.0000569.

[2] “O. Cretu, R. Stewart, T. Berends. 2011. Risk Management for Design and Construction, John Wiley and Sons, Inc., Hoboken NJ," p. 2011, 2011.

[3] C. Sheehan and J. Harrington, "Management of dredge material in the Republic of Ireland - A review," Waste Manag., vol. 32, no. 5, pp. 1031-1044, 2012, doi: 10.1016/j.wasman.2011.11.014.

[4] “Herjanto,eddy,1999, 'Manajemen Produksi dan Operasi', PT. Gramedia Widiasarana Indonesia,Jakarta,” p. $1999,1999$.

[5] B. Render, J. Heizer, J. Heizer, B. Render, and K. Watson, "Web-Based Instruction Improves Teaching Web-Based Instruction Improves Teaching," no. January 2009, 2014.

[6] "Barie, 1984.pdf." .

[7] R. With, C. By, T. Hegazy, and N. Wassef, “COST OPTIMIZATION IN PROJECTS WITH REPETITIVE,” no. June, pp. 183-191, 2001.

[8] "Setianto, A. 2004. Studi Perbandingan Metode BarChart dengan Line of Balance Dalam Penjadwalan Kegiatan Pembangunan Perumahan, Tesis, Universitas Islam Sultan Agung, Semarang.," p. 2004, 2004.

[9] "Sanjaya dan Prawira, 2014., Studi Perbandingan Penjadwalan Proyek Metode Line of Balance dan Diagram Method pada Pekerjaan Berulang, Tugas Akhir., Universitas Diponegoro., Semarang," p. 2014, 2014.

[10] F. Dienyah, "Kontribusi Infrastruktur Terhadap PDRB Provinsi di Pulau Sumatra," Univ. Bandar Lampung, pp. 1-14, 2016.

[11] R. Andriani and B. Susetyo, "Factors Causing Overbudget for Roof Cover Work in the Construction of High-rise Buildings," Int. J. Eng. Res. Adv. Technol., vol. 5, no. 5, pp. 10-18, 2019, doi: 10.31695/ijerat.2019.3434.

[12] W. Alaghbari, M. R. A. Kadir, A. Salim, and Ernawati, "The significant factors causing delay of building construction projects in Malaysia,” Eng. Constr. Archit. Manag., vol. 14, no. 2, pp. 192-206, 2007, doi: 10.1108/09699980710731308. 